\title{
Turismo rural sí, pero solo si es respetuoso con los habitantes
}

\author{
Lidia María Díaz Terán | presidenta de la Asociación Española Contra la Despoblación (AECD)
}

URL de la contribución <www.iaph.es/revistaph/index.php/revistaph/article/view/4446>

Desde el punto de vista de la Asociación Española Contra la Despoblación (AECD) ${ }^{1}$ hay una posibilidad real de que siga existiendo patrimonio cultural material sin que esté presente ninguna comunidad, la prueba la tenemos en los yacimientos arqueológicos alejados a cualquier población, ermitas y monasterios, que reciben visitas turístico-culturales de cualquier parte del mundo.

Cosa bien distinta es que pueda seguir habiendo patrimonio cultural inmaterial con sentido de arraigo y que signifique un vínculo para que se pueda mantener el sentimiento de comunidad.

La comunidad se crea con tiempo y con personas, en los pueblos y en los barrios durante años, se habla de temas comunes con vivencias conjuntas, fiestas que han creado y realizado, tradiciones que fueron desapareciendo, no solo por la falta de personas que las mantuvieran también por los nuevos recursos que existen, y que sin embargo hacían patente y fomentaban el sentido de identidad.

En todo momento hablamos de tradiciones que unen y crean comunidad, en ningún caso nos aferramos al pasado donde estas tradiciones supongan una mirada sesgada hacia personas de distinto género o procedencia y hacia la naturaleza.

Siguiendo la misma línea, observamos que las casas habitadas como segunda vivienda no suelen integrarse en los pueblos aunque sí sociabilizan, por varios motivos lógicos. Las personas que utilizan los pueblos como segunda residencia no pueden vivir el día a día, conocer y sentir las dificultades así como las ventajas y beneficios de vivir en el mundo rural.

Es importante recalcar que las segundas viviendas apenas generan ingresos a los ayuntamientos, la mayoría no están empadronados y no computan en la suma del padrón, sin embargo sí generan a los ayuntamientos una serie de gastos que, como hemos dicho, no vuelve a las arcas municipales.

Otra causa que impide a las personas propietarias de segundas viviendas vacacionales integrarse como comunidad es que no pueden votar; aunque parezca intranscendente, es un hecho importante para la pertenencia a una comunidad rural, donde los vínculos para personas que no pertenecen al pueblo o valle se hilan con tiempo y narraciones continuas.

El hecho de que en muchos casos los pueblos sean considerados destinos turísticos en vez de un lugar propio con sus vecinos, sus tradiciones, cultura y trabajo, provoca que veamos pueblos con las casas arregladas y sus calles vacías, sólo se llenan en épocas vacacionales, los precios de las viviendas se elevan hasta el punto que las personas y sobre todo los jóvenes que desean quedarse a vivir y trabajar en los pueblos no tengan acceso a una vivienda con precios que puedan adquirir, tampoco tienen acceso a alquilar ya que o bien no se alquilan o bien son precios turísticos demasiado elevados.

En todo caso, consideramos que el turismo es necesario y bueno para el desarrollo rural, siempre y cuando sea realizado de una manera sostenible, que signifique creación de trabajo digno para las personas que viven en el medio rural con la consecuencia de fijar la población que existe e ingresos continuos para los municipios.

Esta población ya existente puede aumentar con población que quiera instalarse en el medio rural combinando y cambiando una serie de leyes, entre las que estaría una que se aplicara a las casas y terrenos abandonados por personas que ya no viven y cuyos herederos y herederas no existan o sea imposible su localización 


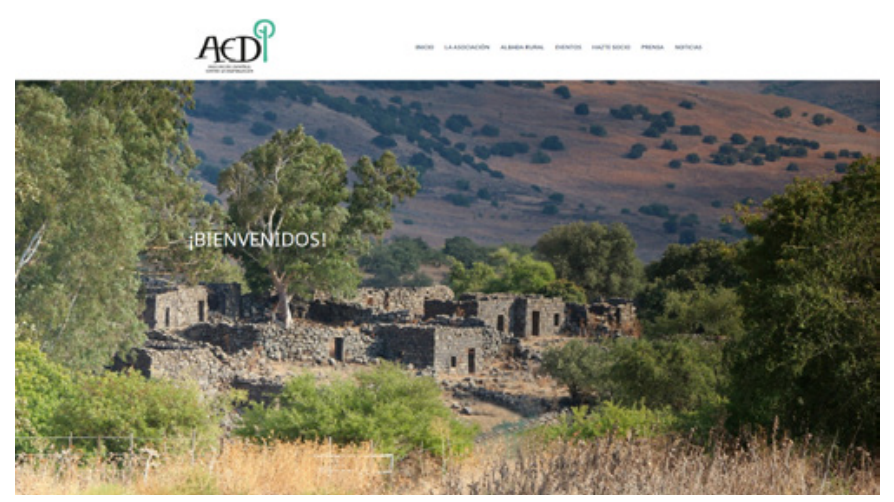

Web Asociación Española Contra la Despoblación

por la gran cantidad de herederos repartidos por cualquier parte del mundo, sin estar especificados, y donde nadie paga los impuestos y nadie trabaja las tierras, tendrían que pasar a titularidad municipal e incluso, si fuera necesario, provincial de manera que, de forma más ágil y sencilla de lo que sucede actualmente, se pudieran realizar proyectos conjuntos con asociaciones, futuros propietarios, etc, que significarían tanto la posibilidad de contar con viviendas a un precio social y con banco de tierras para los nuevos pobladores, que incluyeran compromisos orientados a la creación de empleo estable y a fijar población que se integraría en la comunidad, como la oportunidad de crear suelo industrial sostenible. Pudiendo también desarrollar políticas culturales donde el patrimonio material e inmaterial sea uno de los objetivos principales, de tal forma que el turismo se sienta atraído, un turismo respetuoso con los pobladores y su entorno.

Cuando llegue el verano nuestros pueblos se llenarán de personas que se acerquen el día de las fiestas, disfrutando de las tradiciones o patrimonio inmaterial, después se irán, alegres e ilusionadas con volver el siguiente año. Sin darse cuenta de que quizá el siguiente año no habrá nadie que pueda organizar ni transmitir nuestra cultura, porque las personas envejecen y se desarraigan para ser cuidadas en residencias ajenas a ellas, porque los jóvenes se van a un lugar donde tengan trabajo y puedan formar una familia en la que sus hijos tengan acceso a un colegio y a una sanidad cercanas.

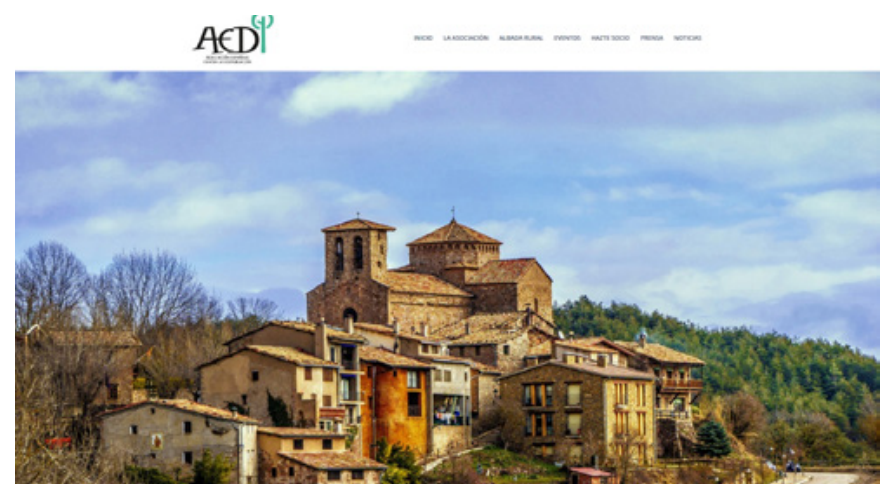

Web Asociación Española Contra la Despoblación

En resumen: el turismo rural es necesario, siempre y cuando se desarrollen estrategias turísticas sostenibles con el entorno y respetuosas con las personas que viven en él, persiguiendo dos objetivos fundamentales: mantener nuestro patrimonio; y fijar la población que existe así como atraer nuevos pobladores que se integren en la vida cotidiana de los pueblos.

\section{NOTA}

1. La Asociación Española Contra la Despoblación nace como consecuencia de encuentros aleatorios entre personas de distintos ámbitos y lugares de España, que coincidimos en una preocupación común, las zonas rurales están envejeciendo y se están vaciando. Las iniciativas que hasta ahora estaban actuando no eran suficientes, los recursos económicos están tan divididos que su dispersión hace imposible su seguimiento, la utilidad de los mismos, y a la vez consigue que se pierdan parte de ellos. Creemos que la solución como entelequia global no existe, sin embargo nuestro interés es el de contribuir y aglutinar a personas y organizaciones que estén dispuestas a luchar por renovar y vivir el mundo rural con dignidad, cada uno manteniendo su identidad propia. 